University of Wollongong

Research Online

Faculty of Engineering - Papers (Archive)

Faculty of Engineering and Information

Sciences

$1-1-2009$

\title{
The performance of rail track incorporating the effects of ballast breakage, confining pressure and geosynthetic reinforcement
}

Buddhima Indraratna

University of Wollongong, indra@uow.edu.au

S Nimbalkar

University of Wollongong, sanjayn@uow.edu.au

D Christie

Follow this and additional works at: https://ro.uow.edu.au/engpapers

Part of the Engineering Commons

https://ro.uow.edu.au/engpapers/854

\section{Recommended Citation}

Indraratna, Buddhima; Nimbalkar, S; and Christie, D: The performance of rail track incorporating the effects of ballast breakage, confining pressure and geosynthetic reinforcement 2009, 5-24.

https://ro.uow.edu.au/engpapers/854

Research Online is the open access institutional repository for the University of Wollongong. For further information contact the UOW Library: research-pubs@uow.edu.au 


\title{
The performance of rail track incorporating the effects of ballast breakage, confining pressure and geosynthetic reinforcement
}

\author{
B. Indraratna \& S. Nimbalkar \\ Department of Civil Engineering, University of Wollongong, NSW, Australia \\ D. Christie \\ RailCorp, Sydney, Australia
}

\begin{abstract}
Rail tracks are often placed on ballast which offers the desirable resiliency to cyclic loads. However ballasted beds need periodic maintenance due to deformation and degradation associated with breakage and fouling. A proper understanding of load transfer mechanisms and their effect on ballast breakage are prerequisites for minimizing maintenance costs. Recycled ballast is a cheaper and environmentally viable option but its strength characteristics need to be investigated beforehand. This paper demonstrates the analytical, numerical and laboratory investigations carried out to investigate the geotechnical behavior of ballast, including shear strength, ballast breakage, and confining pressure. The potential use of geosynthetics for improving the stability and drainage of railway tracks under high monotonic and cyclic loading is also studied. Field tests were carried out to measure the in-situ stresses of ballast on a section of instrumented track funded and built by RailCorp, Australia.
\end{abstract}

\section{INTRODUCTION}

Rail roads form the largest worldwide network catering for quick and safe, public and freight transportation. In order to compete with the other modes of transportation and meet the ever growing demand of public and freight transport, railway industries face challenges to improve their efficiency and decrease maintenance and infrastructure costs. In spite of recent advances in rail geotechnics, the correct choice of ballast for rail track foundation is still considered critical because aggregates progressively deteriorate and break down under heavy cyclic loading. The degradation of ballast is influenced by factors including the amplitude and number of load cycles, gradation of aggregates, track confining pressure, and the angularity and fracture strength of individual grains. The cost of track maintenance can be significantly reduced if the geotechnical behaviour of rail substructure, in particular the ballast layer, is better understood. The use of geosynthetics beneath the layer of ballast as drainage, confinement and to separate it from subballast, is highly desirable. The potential use of recycled ballast in the rail track reinforced with geosynthetics is also an economically feasible option.

\section{GEOTECHNICAL BEHAVIOR OF BALLAST}

Ballast forms the largest component of a rail track by weight and volume. Ballast materials usually include dolomite, rheolite, gneiss, basalt, granite and quartzite (Raymond, 1979). It is composed of medium to coarse gravel sized aggregates $(10-60 \mathrm{~mm})$ with a smaller percentage of cobble-sized particles. Good quality ballast should possess angular particles, have a high specific gravity, a high shear strength, a high toughness and hardness, a high resistance to weathering, a rough surface, and a minimum of hairline cracks (Indraratna et al. 1998). The main functions of ballast are (Selig \& Waters, 1994): distributing and damping the loads received from sleepers, producing lateral resistance, and providing rapid drainage. It could be argued that for high load bearing characteristics and maximum track stability, ballast needs 
to be angular, well graded, and compact, which in turn reduces drainage. Therefore the use of geosynthetics as a suitable alternative for drainage and separation of ballast and subballast needs to be investigated. In this paper the geotechnical properties of ballast are discussed. The effect of geosynthetics on rail track performance for both fresh and recycled ballast is discussed. It is shown that using geosynthetics with special characteristics in the track bed improves its performance significantly.

\subsection{Shear strength}

The shear strength of granular materials is generally assumed to vary linearly with the applied stress and the Mohr-Coulomb theory is usually used to describe conventional shear behavior. Indraratna et al. (1997) have shown that the shear strength is a function of confining pressure, and is highly non-linear at high stresses. Indraratna et al. (1993) proposed a non-linear strength envelope obtained during the testing of granular media at low normal stresses. This non-linear shear stress envelope is represented by the following equation:

$$
\tau_{f} / \sigma_{c}=m\left(\sigma_{n}^{\prime} / \sigma_{c}\right)^{n}
$$

where $\tau_{f}$ is the shear stress at failure, $\sigma_{c}$ is the uniaxial compressive stress of the parent rock determined from the point load test, $m$ and $n$ are dimensionless constants, and $\sigma_{n}^{\prime}$ is the effective normal stress. The non-linearity of the stress envelope is governed by the coefficient $n$. For the usual range of confining pressures (below $200 \mathrm{kPa}$ ) for rail tracks, $n$ takes values in the order of $0.65-0.75$. A large-scale cylindrical triaxial apparatus, which could accommodate specimens of $300 \mathrm{~mm}$ diameter and $600 \mathrm{~mm}$ high (see Figure 1), was used by Indraratna et al. (1998) to verify the non-linearity of shear stress. The results of his study associated with latite basalt in a normalized form are plotted in Figure 2, with results obtained from other researchers (Marsal, 1973; Marachi et al. 1972; Charles \& Watts, 1980).

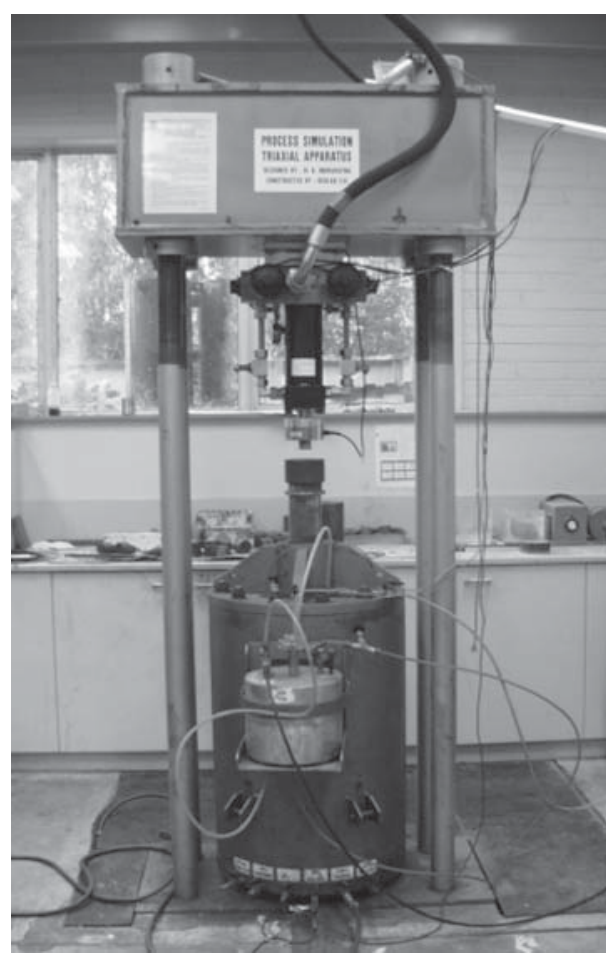

Figure 1. Cylindrical triaxial apparatus with dynamic actuator design at UoW. 


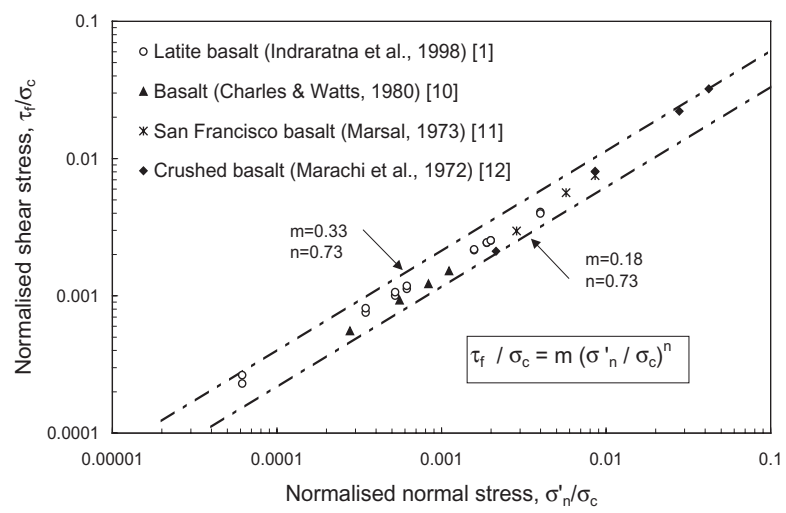

Figure 2. Normalized shear strength for latite basalt aggregates (Indraratna et al. 1998).

\subsection{Ballast breakage}

Railway tracks are deformed by the degradation of ballast particles (Selig \& Waters, 1994; Indraratna et al. 1998, 2001). Their breakage under load is a complex mechanism that usually starts at the inter-particle contacts (i.e. breakage of asperities), followed by a complete crushing of weaker particles under further loading. A rapid fragmentation of particles and subsequent clogging of voids with fines is commonly observed in overstressed railway foundations. Chrismer \& Read (1994) concluded that the degradation of aggregate is the primary cause of contamination, and accounts for up to $40 \%$ of the fouled material. Generally, the main factors that affect breakage can be divided into three categories: (a) properties related to the characteristics of the parent rock (e.g. hardness, specific gravity, toughness, weathering, mineralogical composition, internal bonding and grain texture); (b) physical properties associated with individual particles (e.g. soundness, durability, particle shape, size, angularity and surface smoothness); and (c) factors related to the assembly of particles and loading conditions (e.g. confining pressure, initial density or porosity, thickness of ballast layer, ballast gradation, presence of water or ballast moisture content, cyclic loading pattern including load amplitude and frequency). The effects of some of these factors are demonstrated in this paper.

In order to quantify ballast breakage in the current study, Marsal's (1967) method was used in which the volume of particle breakage while loading a specimen of ballast is defined by the changes in particle size distribution curves measured before and after loading. Marsal introduced a breakage index $\mathrm{B}_{g}$, which is the sum of the difference in percentage retained on sieves, having the same sign.

Indraratna et al. (2005) introduced an alternative ballast breakage index (BBI) based on particle size distribution (PSD) curves. The ballast breakage index (BBI) is calculated on the basis of change in the fraction passing a range of sieves, as shown in Figure 3. The increase in degree of breakage causes the PSD curve to shift further towards the smaller particles size region on a conventional PSD plot. The area A between the initial and final PSD increases results in a greater BBI value. BBI has a lower limit of 0 (no breakage) and an upper limit of 1 . By referring to the linear particle size axis, BBI can be calculated by using following equation.

$$
\mathrm{BBI}=\frac{\mathrm{A}+\mathrm{B}}{\mathrm{A}}
$$

where $\mathrm{A}$ is the area as defined previously, and $\mathrm{B}$ is the potential breakage or area between the arbitrary boundary of maximum breakage and the final particle size distribution.

\subsection{Constitutive modelling of ballast}

Salim \& Indraratna (2004) developed an elasto-plastic stress-strain constitutive model incorporating dilatancy, breakage and the plastic flow rule to predict ballast deformation and 


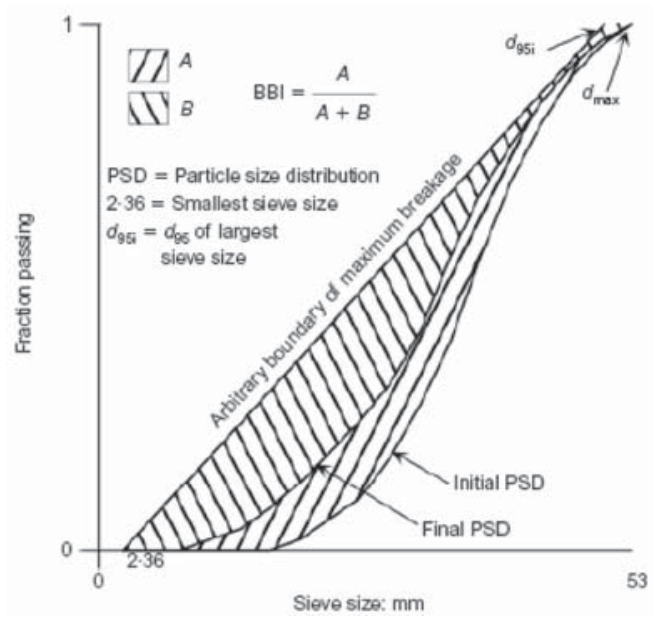

Figure 3. Ballast breakage index (BBI) calculation method (Indraratna et al. 2005).

degradation. The model uses a generalized 3D system to define the contact forces, stresses and strains in granular media, including the plastic potential, the hardening function, and particle breakage. This model is based on the critical state concept and theory of plasticity with a kinematic-type yield locus (constant stress ratio). The increments of plastic distortional strain $d \varepsilon_{s}^{p}$, and volumetric strain $d \varepsilon^{p}$, were given by Salim \& Indraratna (2004), as follows:

$$
\begin{gathered}
d \varepsilon_{s}^{p}=\frac{2 \alpha \kappa\left(\frac{p}{p_{c s}}\right)\left(1-\frac{p_{o(i)}}{p_{c s(i)}}\right)\left(9+3 M-2 \eta^{*} M\right)\left(\eta-\eta_{i}\right) d \eta}{\left(M-\eta_{i}\right)^{2}\left(1+e_{i}\right)\left(\frac{2 p_{o}}{p}-1\right)\left[9\left(M-\eta^{*}\right)+\frac{B}{p}\left\{\chi+\mu\left(M-\eta^{*}\right)\right\}\right]} \\
d \varepsilon_{v}^{p}=\frac{9(M-\eta)}{9+3 M-2 \eta^{*} M} d \varepsilon_{s}^{p}+\left(\frac{B}{p}\right)\left[\frac{\chi+\mu\left(M-\eta^{*}\right)}{9+3 M-2 \eta^{*} M}\right] d \varepsilon_{s}^{p}
\end{gathered}
$$

The parameter $p$ is the effective mean stress and $p_{c s}$ is the value of $p$ on the critical state line at the current void ratio. $p_{o}$ is the value of $p$ at the intersection of the undrained stress path and the initial stress ratio line. The sub-script $i$ indicates the initial value at the start of shearing. The parameter $\eta$ is the stress ratio $(\eta=q / p), q$ is the deviator stress, $\eta^{*}=\eta\left(p / p_{c s}\right), M$ is the critical state stress ratio, $e_{i}$ is the initial void ratio, $\kappa$ is the negative slope of compression curve $(e-\ln p)$ and $\alpha, B, \chi$ and $\mu$ are dimensionless constants. The evolutionary techniques of these constants are given in Salim \& Indraratna (2002). This model was verified using large-scale triaxial tests (see Figure 4). The above constitutive model contains 11 parameters for monotonic loading and additional 4 parameters for cyclic loading. These parameters can be evaluated using the results of the drained triaxial test and the measurements of particle breakage.

\subsection{Effect of confining pressure}

Although the effect confining pressure on various geotechnical structures is significant and is considered to be key criteria in the design of these structures, it is usually neglected in conventional rail track design. Track substructure is essentially self-supporting with minimal lateral constraints. During a train passage, ballast and capping (subballast) materials are free to spread laterally, which increases track settlement and decreases its shear strength. At the University of Wollongong, cyclic triaxial tests have been conducted on samples of ballast to investigate the effect of confining pressure. Track confinement can be increased by reducing the spacing of sleepers, increasing the height of shoulder ballast, including a geosynthetic layer at the ballast-subballast interface, widening the sleepers at both ends (see Figure 5), and 

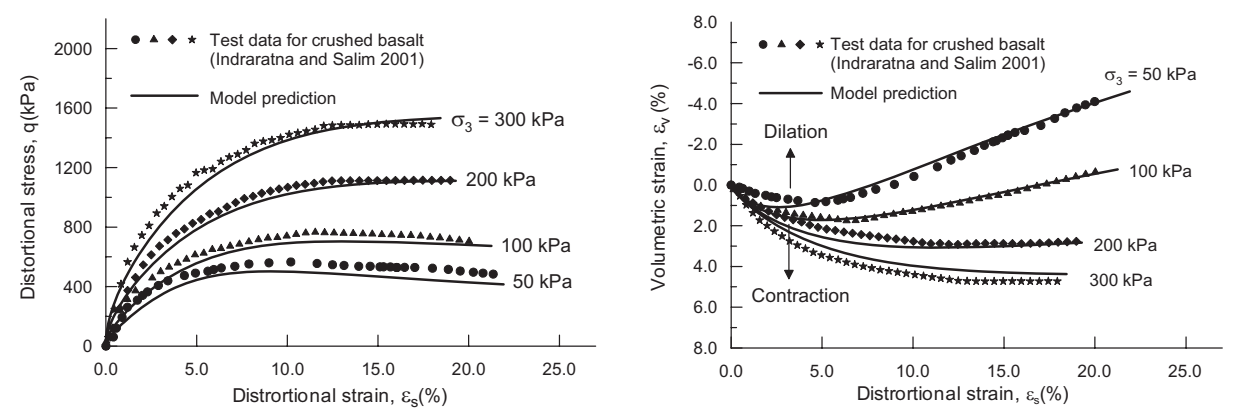

Figure 4. Model prediction compared with experimental data for drained triaxial shearing (Salim \& Indraratna, 2004).

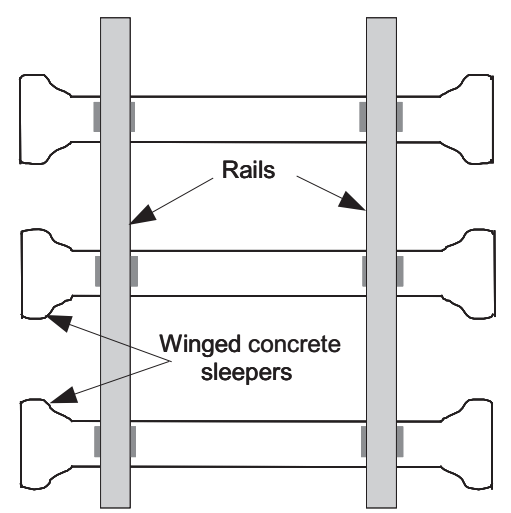

Figure 5. Sleepers with enlarged ends to increase the confining pressure (Indraratna et al. 2004).

using intermittent lateral restraints at various parts of the track (see Figure 6). The effect of confining pressure on ballast under cyclic loading to reduce the volume of breakage has been studied by Indraratna et al. (2005) and Lackenby et al. (2007) to find out the optimum confining pressure based on loading and track conditions.

Specimenswere prepared to therecommended gradationandinitialporosity (i.e. $d_{50}=38.5 \mathrm{~mm}$, $C_{u}=1.54 . e_{o}=0.76$ where $d_{50}$ is the ballast diameter corresponding to $50 \%$ finer in the particle size distribution curve and $C_{u}$ is the coefficient of uniformity). Effective confining pressures $\left(\sigma_{3}^{\prime}\right)$ ranging from 1 to $240 \mathrm{kPa}$ with $q_{\max }=500 \mathrm{kPa}$ were applied. Figure 7 shows the results of confining pressure $\left(\sigma_{3}^{\prime}\right)$ on the axial and volumetric strains of ballast achieved at the end of 500,000 cycles. As expected, the axial strains decreased with an increasing confining pressure and the specimens dilated at a low confining pressure $\left(\sigma_{3}^{\prime}<30\right)$, but became progressively more compressive as the confining pressure increased from 30 to $240 \mathrm{kPa}$.

The effect of confining pressure $\left(\sigma_{3}^{\prime}\right)$ on particle degradation is shown in Figure 8, where breakage was divided into three regions: (I) a dilatant unstable degradation zone (DUDZ); (II) an optimum degradation zone (ODZ); and (III) a compressive stable degradation zone (CSDZ). Lackenby et al. (2007) has shown that the specimens are subjected to rapid and considerable axial and expansive radial strains that result in an overall volumetric increase or dilation at low confining pressure of DUDZ region $\left(\sigma_{3}^{\prime}<30 \mathrm{kPa}\right)$. Particles in this region are given insufficient time to rearrange and due to the excessive axial and radial strains, a considerable degradation occurs as a result of shearing and attrition of angular projections. Due to the low confining pressures applied in this region, specimens in this degradation zone are characterized by limited particle-to-particle areas of contact.

As the confining pressure is increased to the ODZ region $\left(\sigma_{3}^{\prime}=30-75 \mathrm{kPa}\right)$, the rate of axial strain is greatly reduced due to an apparent increase in stiffness, and the overall 


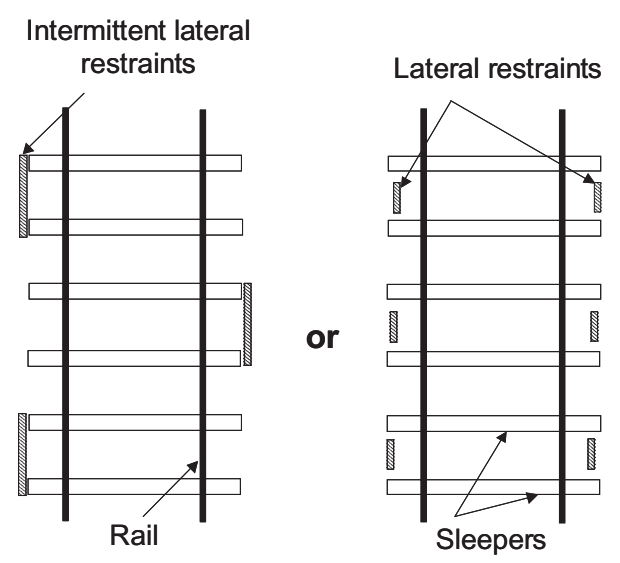

Figure 6. Increasing confining pressure using intermittent lateral restraints (Indraratna et al. 2004).

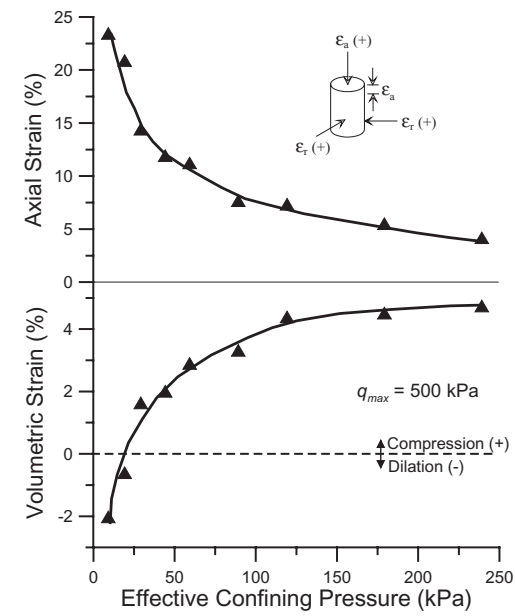

Figure 7. Variation of axial and volumetric strains with confining pressure (Lackenby et al. 2007).

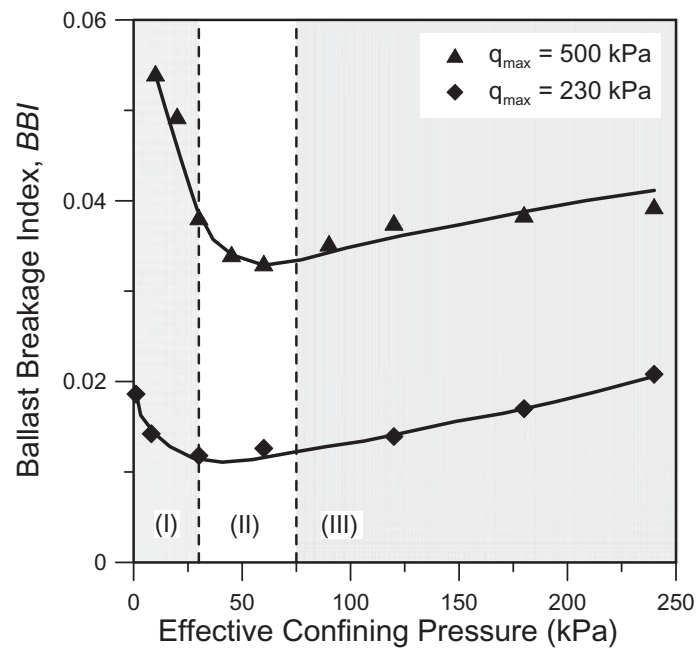

Figure 8. Effect of confining pressure on particle degradation (Lackenby et al. 2007). 
volumetric behaviour is slightly compressive. Particles in this region are held together in an optimum array with sufficient lateral confinement so as to provide an optimum distribution of contact stress and increased areas of inter-particle contact which reduces the risk of breakage associated with concentrations of stress. As $\sigma_{3}^{\prime}$ is increased further in the CSDZ region $\left(\sigma_{3}^{\prime}>75 \mathrm{kPa}\right)$, the particles are forced against each other which limits sliding and rolling but increases their breakage considerably. Particles in this region fail not only at the beginning of loading when axial strain rates are greatest, but also by fatigue as the number of cycles increase. Due to the large lateral forces being applied to the samples in this region, volumetric compression is enhanced, which is partly due to an increase in particle breakage.

\section{RESILIENT MODULUS OF BALLAST}

The cyclic response of ballast is usually characterised by the resilient modulus. For repeated loads in triaxial testing with constant confining stress, the resilient modulus $\left(M_{R}\right)$ is defined as the ratio of the applied cyclic deviator stress to the recoverable (resilient) axial strain during unloading as illustrated in Figure 9 (a) and (b). Resilient modulus is defined as

$$
M_{R}=\frac{\Delta q}{\varepsilon_{r}}
$$

where $\Delta q$ is the difference between $q_{\max }$ and $q_{\min }$ and $\varepsilon_{r}$ is the recoverable (resilient) axial strain during triaxial unloading. Indraratna et al. (2008) highlighted the influence of particle breakage on the resilient modulus which is summarised below.

\subsection{Resilient modulus and bulk stress}

The resilient modulus of granular materials can be expressed by a simple hyperbolic model popularly known as K- $\varphi$ model (Hicks, 1970). This model expresses $M_{R}$ as a function of the sum of principal stresses $\left(s_{1}^{\prime}+s_{2}^{\prime}+s_{3}^{\prime}\right)$ also known as the bulk stress $(\Sigma \psi \mu \beta \mathrm{o})$

$$
M_{R}=k_{1} \varphi^{k 2}
$$

where $\mathrm{k}_{1}$ and $\mathrm{k}_{2}$ are empirical coefficients.

For triaxial tests, due to symmetry in directions (2) and (3), $\left(\sigma_{2}^{\prime}=\sigma_{3}^{\prime}\right)$, the sum of the principal stress simplifies to $\left(\sigma_{2}^{\prime}+2 \sigma_{3}^{\prime}\right)$.

Figure 10 presents the variation of $M_{R}$ with $\varphi$ for different values of $\sigma_{3}^{\prime}$ and $q_{\max }$. It is shown that all values of $M_{R}$ irrespective of $\sigma_{3}^{\prime}$ and $q_{\max }$ fall within a narrow band. Thus a
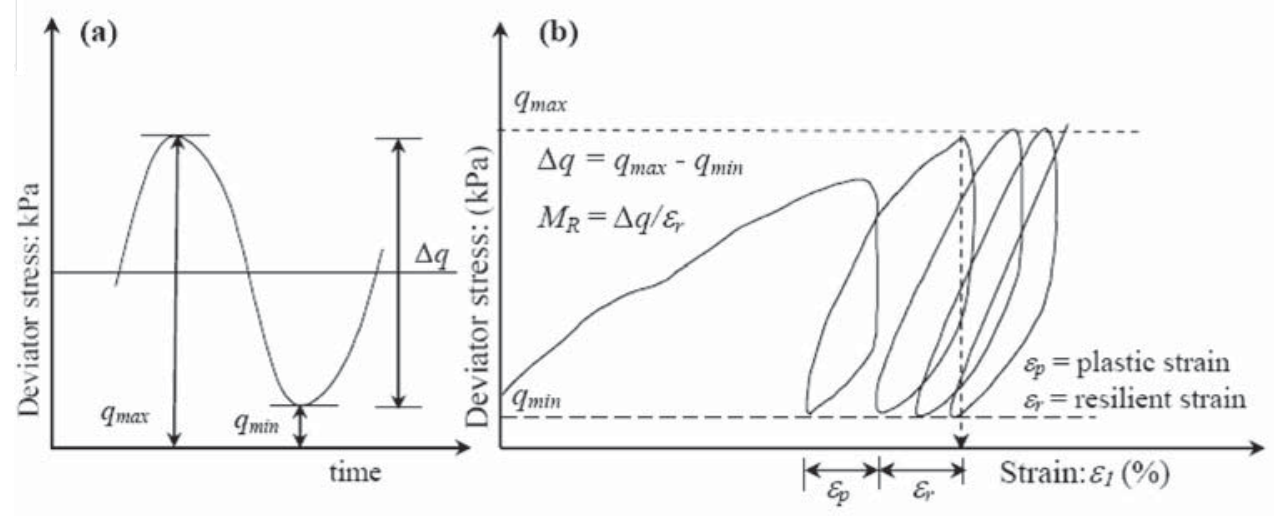

Figure 9. (a) cyclic loading curve, showing the maximum and minimum deviator stress, (b) representation of strains during one cycle of load application (Indraratna et al. 2008). 


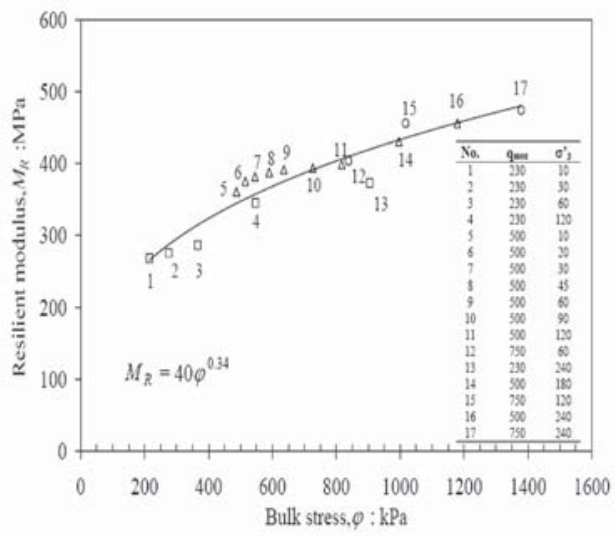

Figure 10. Relationship between resilient modulus and bulk stress (Indraratna et al. 2008).

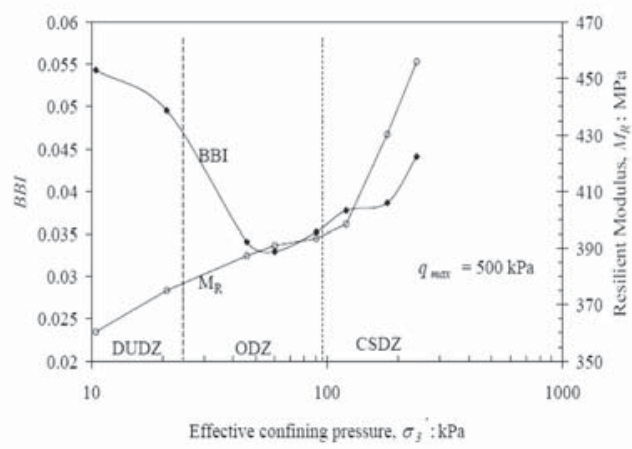

Figure 11. Variation of $\mathrm{BBI}$ and $M_{R}$ with $\sigma_{3}^{\prime}$ for cyclic deviator stress of $500 \mathrm{kPa}$ (Indraratna et al. 2008).

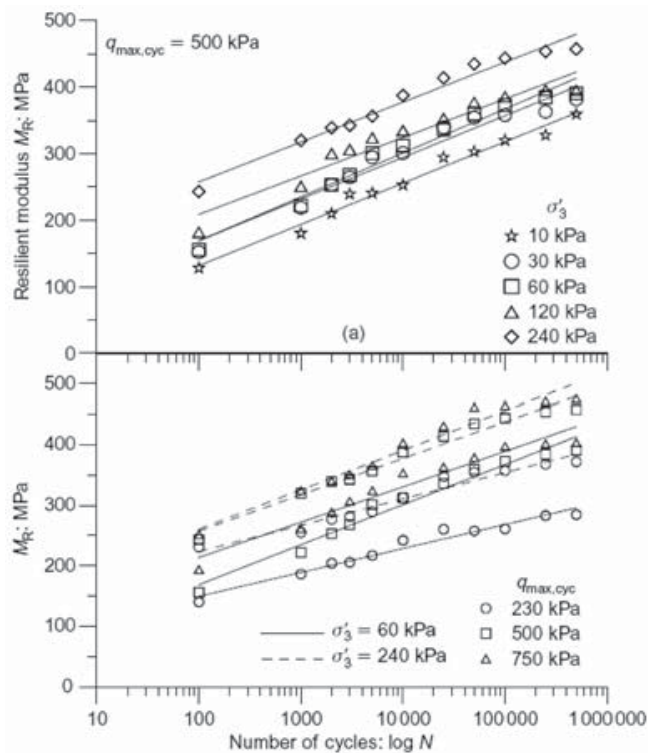

(b)

Figure 12. (a) Effect of confining pressure and the number of cycles on $M_{R}$, (b) effect of $q_{\text {max,cyc }}$ on $M_{R}$ (Lackenby et al. 2007). 
unique relationship between the resilient modulus and bulk stress, given by $M_{R}=40 \varphi^{0.34}\left(R^{2}\right.$ $>0.95$ ) predicts well the resilient action of ballast.

\subsection{Resilient modulus and ballast breakage}

Figure 11 presents the variation of $\mathrm{BBI}$ and $M_{R}$ with $\sigma_{3}^{\prime}$ for a constant maximum deviator stress $\left(q_{\max }\right) 500 \mathrm{kPa}$. Also the boundaries of the ballast degradation zones are shown. Here $M_{R}$ increases gradually with $\sigma_{3}^{\prime}$ in both the DUDZ and ODZ zones. However, there is a marked increase in $M_{R}$ in the compressive (CSDZ) region as $\sigma_{3}^{\prime}$ exceeds $65 \mathrm{kPa}$. The percentage increase of $M_{R}$ in this zone was found to be $16 \%$ for $q_{\max }$ of $500 \mathrm{kPa}$. An increased $\sigma_{3}^{\prime}$ in the CSDZ will increase the stress level where the particles touch whilst restricting internal sliding and rolling (Lackenby et al. 2007; Indraratna et al. 2008), and contribute towards an increase in the resilient modulus. Lackenby et al, 2007 has shown that the resilient modulus $\left(M_{R}\right)$ increases with an increasing number of cycles, and a maximum deviator stress magnitude $\left(q_{\text {max,cyc }}\right)$ and confining pressure, as shown in Figure 12.

\section{USE OF GEOSYNTHETICS FOR STABILIZING A RECYCLED BALLASTED TRACK}

Geo-synthetics have been widely and successfully used in new rail tracks and track rehabilitation for almost three decades. When appropriately designed and installed, geosynthetics are a cost effective alternative to more traditional techniques. Railway tracks still have several problem areas with ballast; an increase in the bearing capacity of subgrade soil, contamination with subgrade fines, and dissipation of high pore water pressure built up by cyclic train loading. As with other geotechnical engineering projects, the application of geosynthetics within railway construction can be subdivided into (1) separation, (2) reinforcement, (3) filtration, (4) drainage, (5) moisture barrier/waterproofing and (6) protection. In order to reduce the accumulation of discarded ballast, minimise the cost of track maintenance and reduce the environmental degradation caused by quarrying more fresh ballast, selected waste ballast may be cleaned, sieved, and reused. However, because the angularity of recycled ballast was diminished by the degradation of sharp corners in previous loading cycles, recycled ballast will deform laterally and settle faster than fresh ballast. Therefore its behavior and performance must be investigated to ensure that it complies with the required stability and safety criteria stipulated by various rail authorities before being re-used.

An extensive laboratory experimental program using a large-scale prismoidal triaxial rig was carried out at the University of Wollongong to investigate how different types of geosynthetics enhanced the mechanical properties of fresh and recycled ballast. A plane strain finite element analysis (PLAXIS) was also used to simulate the behavior of ballast in a prismoidal tri-axial rig, with and without geosynthetics. This finite element model was then used to obtain the optimum location for geosynthetics in track substructure. The laboratory experiments and finite element analysis, including their findings, are described and explained below.

\subsection{Laboratory model experiments}

A large-scale prismoidal triaxial rig, $800 \mathrm{~mm}$ long $\times 600 \mathrm{~mm}$ wide $\times 600 \mathrm{~mm}$ high was built at the University of Wollongong to model the response of ballasted tracks to cyclic loading. Figure 13 shows the rig and Figure 14 shows a schematic view. Further details of this apparatus can be found in Indraratna et al. (2003).

Fresh ballast that consisted of sharp angular aggregates of crushed volcanic ballast (latite) was collected from Bombo quarry, situated near the city of Wollongong. Recycled ballast that consisted of semi-angular crushed rock fragments was collected from an existing stockpile at Chullora, in Sydney. The capping layer was a compacted mixture of fine gravel and sand $\left(d_{50}=0.26 \mathrm{~mm}, C_{u}=5\right)$. All the fresh and recycled specimens of ballast were prepared following a single gradation curve $\left(d_{50}=35 \mathrm{~mm}, C_{u}=1.6\right)$. A geosynthetic reinforcement layer was placed at the ballast-capping interface. 


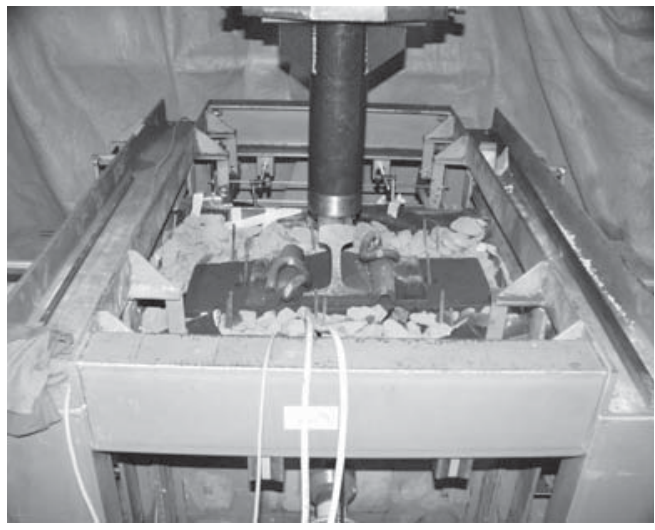

Figure 13. Large-scale prismoidal triaxial equipment designed at the UoW.

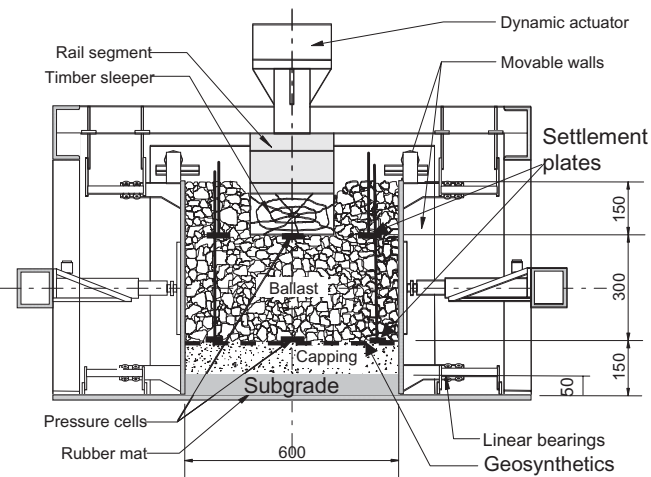

Figure 14. Schematic view of the large-scale prismoidal triaxial apparatus (Indraratna et al. 2003).

Three types of geosynthetics (i.e. geogrid, woven-geotextile and geocomposite) were used to stabilise both the fresh and recycled ballast. The geosynthetics were all made from polypropylene. The geogrid was bi-oriented with $27 \mathrm{~mm} \times 40 \mathrm{~mm}$ rectangular apertures and $420 \mathrm{~g} / \mathrm{m}^{2}$ unit mass. Its peak tensile strength was $30 \mathrm{kN} / \mathrm{m}$. The geotextile was a high strength woven polymer with $0.25 \mathrm{~mm}$ pores, $450 \mathrm{~g} / \mathrm{m}^{2}$ unit mass, and $80 \mathrm{kN} / \mathrm{m}$ tensile strength. The geocomposite had a unit mass of $560 \mathrm{~g} / \mathrm{m}^{2}$ and was composed of the same geogrid bonded to a non-woven polypropylene geotextile. The purpose of adding the non-woven geotextile to the geogrid was to provide filtration and separation functions that are absent in the geogrid due to its large apertures. In order to simulate real track conditions, the prismoidal triaxial chamber was filled with several layers of ballast and other material; a $50 \mathrm{~mm}$ layer of compacted clay on the bottom, a $100 \mathrm{~mm}$ capping layer, then a $300 \mathrm{~mm}$ layer of load bearing ballast, and $150 \mathrm{~mm}$ layer of crib ballast on top. Finally, a $650 \mathrm{~mm}$ long $\times 220 \mathrm{~mm}$ wide timber sleeper and a segment of rail were placed above this compacted ballast.

The space between the sleeper and the walls was filled with crib ballast. After preparing the specimen, small lateral stresses $\left(\sigma_{2}^{\prime}=10 \mathrm{kPa}\right.$ and $\left.\sigma_{3}^{\prime}=7 \mathrm{kPa}\right)$ were applied to the walls of the triaxial chamber by hydraulic jacks to simulate shoulder ballast and field confining stresses. A cyclic load was applied with a maximum load intensity of $73 \mathrm{kN}$ to produce the same average contact stress at the sleeper-ballast interface for a typical 25 tonne/axle traffic load. The tests were conducted at a frequency of $15 \mathrm{~Hz}$ to simulate a speed of $80 \mathrm{~km} / \mathrm{h}$. The total number of load cycles applied in each test was 500,000. More detailed procedures, together with the complete findings and discussions of the tests were reported by Indraratna et al. (2004). Only some of the test results are summarised below. 


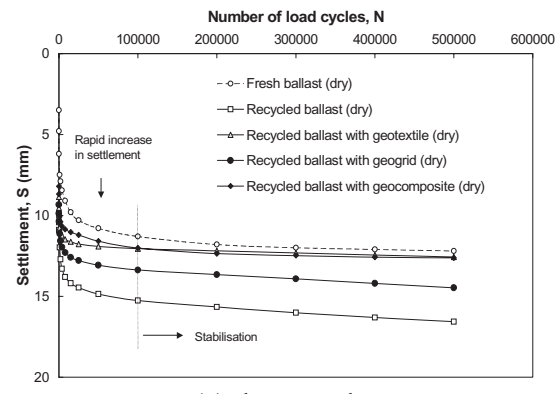

(a) dry samples

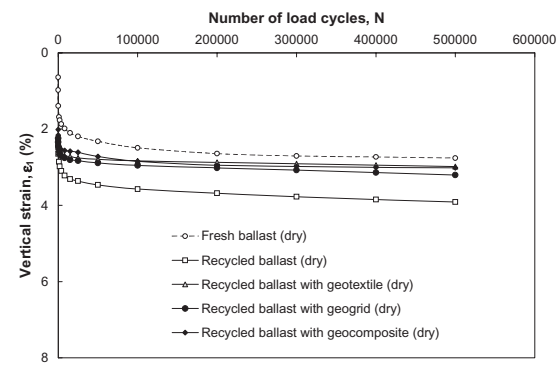

(a) dry samples

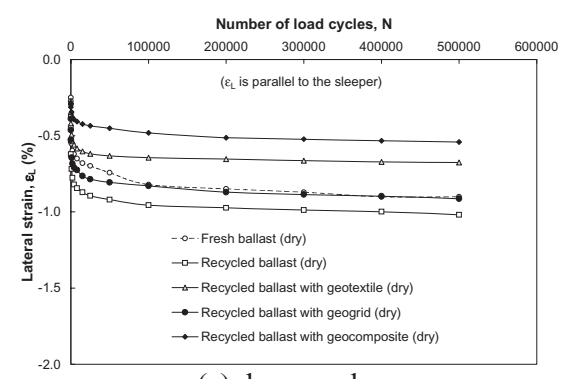

(a) dry samples

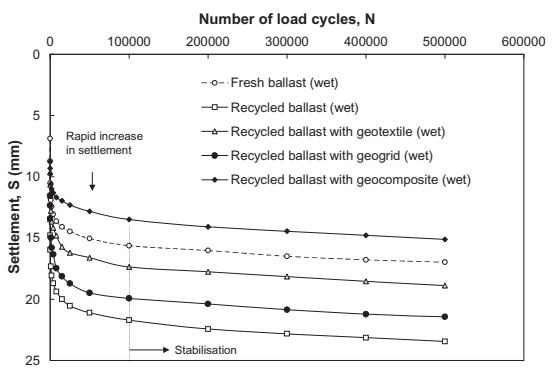

(b) wet samples

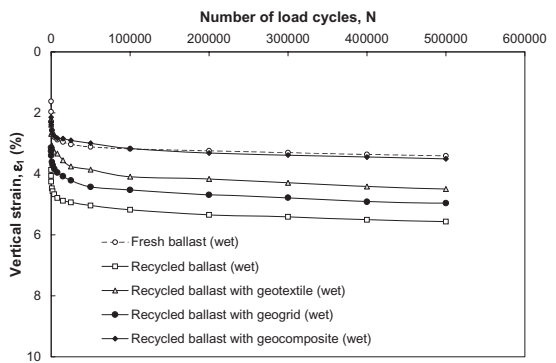

(b) wet samples

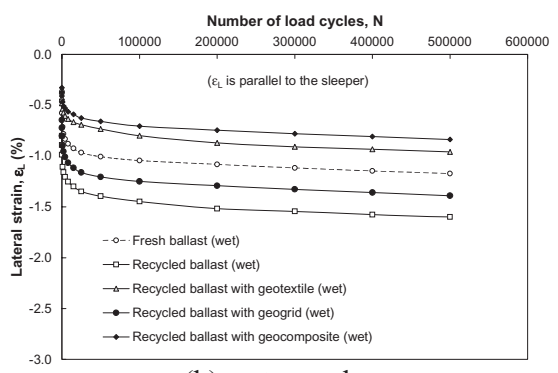

(b) wet samples

Figure 15. Effect of geosynthetics on the settlement, vertical strain and lateral strain of ballast (Indraratna \& Salim 2005; Salim 2004).

Figure 15 shows the effect of geosynthetics on the settlement, vertical strain and lateral strain of ballast under wet and dry conditions. As expected there was less deformation (i.e. settlement, vertical strain and lateral strain) with fresh ballast than with recycled ballast. It is believed that the higher angularity of fresh ballast enables the particles to interlock better and cause less deformation. The test results revealed that wet recycled ballast (without any geosynthetic inclusion) was quite deformed, probably because water acts as a lubricant, reducing frictional resistance and promoting particle slippage. Although geogrids and woven geotextiles decrease the deformation of recycled ballast considerably, the geocomposite (geogrid bonded with non-woven geotextile) stabilise recycled ballast remarkably well.

As described by Rowe \& Jones (2000), geocomposites can provide reinforcement to the ballast layer and simultaneous filtration and separation functions. This combination of geogrid reinforcement, filtration, and separation by the bonded non-woven geotextile reduces lateral spreading, fouling, and degradation, especially in wet conditions. The geotextile also prevents fines moving up from the capping and subgrade layers (subgrade pumping) to keep the recycled ballast relatively clean.

To study ballast breakage in terms of the breakage index $B_{g}$ as proposed by Marsal (1967), each specimen of ballast was sieved before and after testing, and the changes in percentage retained on each size sieve were recorded. The breakage index values of recycled ballast 
stabilised with geocomposites in dry and wet conditions were almost the same as fresh ballast (without geocomposites), and approximately 50\% lower than recycled ballast without geosynthetics. This clearly indicates the benefits of using geosynthetics to reduce breakage of ballast under both dry and saturated conditions.

It is evident from Table 1 that recycled ballast stabilised with geocomposites $\left(B_{g}=1.60\right)$ is as good as fresh ballast $\left(B_{g}=1.63\right)$ in terms of breakage assessment.

\subsection{Numerical modelling using PLAXIS}

A layer of geosynthetics could be placed anywhere beneath a sleeper and within the ballast layer to improve its deformation characteristics, but the geosynthetics must be at an adequate depth below the sleeper to allow for tamping and subsequent maintenance of the track (i.e. removal of used ballast and replacing with fresh aggregates). With new tracks, geosynthetics are installed directly on the formation or subballast layer (Raymond, 2002), but with track rehabilitation they are installed on top of the old ballast which has either been trimmed or embedded in the original subgrade formation (Ashpiz et al., 2002). A finite element analysis (PLAXIS) was used to determine its optimum location.

The large-scale prismoidal triaxial rig shown in Figures 13 and 14 was numerically discretized using the mesh shown in Figure 16. Due to symmetry, only half the rig was used in the numerical model. The material parameters and constitutive models used for each component of the track section are given in Table 2. Full details on constitutive models summarized in Table 2 and their parameters can be found in PLAXIS manual. A train load was simulated by applying an equivalent, uniformly distributed vertical dynamic load on the sleeper. This dynamic load has the same average contact stress at the

Table 1. Effect of geosynthetics on Marshal's breakage index $\left(B_{g}\right)$.

\begin{tabular}{lll}
\hline & \multicolumn{2}{l}{ Breakage index, $B_{g}=\sum(\Delta W K>0)$} \\
\cline { 2 - 3 } Type of test & Sample in dry condition & Sample in wet condition \\
\hline Fresh ballast & 1.50 & 1.63 \\
Recycled ballast & 2.96 & 3.19 \\
Recycled ballast with geogrid & 1.70 & 1.88 \\
Recycled ballast with geotextile & 1.56 & 1.64 \\
Recycled ballast with geocomposite & 1.52 & 1.60 \\
\hline
\end{tabular}

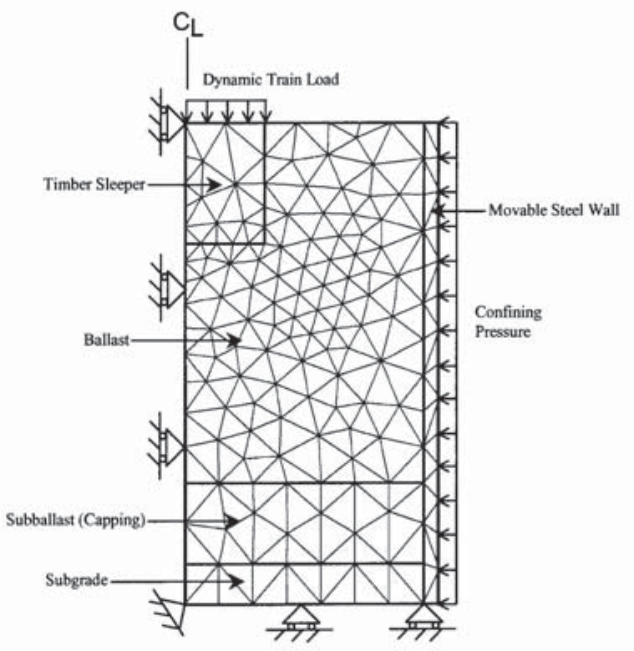

Figure 16. Finite element mesh used in PLAXIS for the prismoidal triaxial apparatus (Indraratna et al. 2005). 
Table 2. Parameters of the rail track materials used in the finite element analysis.

\begin{tabular}{|c|c|c|c|c|c|c|c|}
\hline \multirow[b]{2}{*}{ Parameter } & \multicolumn{2}{|c|}{ Ballast } & \multirow[b]{2}{*}{ Subballast } & \multirow[b]{2}{*}{ Subgrade } & \multirow{2}{*}{$\begin{array}{l}\text { Timber } \\
\text { sleeper }\end{array}$} & \multirow[b]{2}{*}{ Steel wall } & \multirow[b]{2}{*}{ Geogrids } \\
\hline & Fresh & Recycled & & & & & \\
\hline Model & HS & HS & $\mathrm{MC}$ & Elastic & Elastic & Elastic & Elastic \\
\hline$\gamma\left(\mathrm{kN} / \mathrm{m}^{3}\right)$ & 15.3 & 15.3 & 21.3 & 17 & - & - & - \\
\hline$E_{50}^{r e f}(\mathrm{MPa})$ & 150 & 70 & - & - & - & - & - \\
\hline$E_{\text {oed }}^{r e f}(\mathrm{MPa})$ & 150 & 70 & - & - & - & - & - \\
\hline$E_{u r}^{r e f}(\mathrm{MPa})$ & 450 & 210 & - & - & - & - & - \\
\hline$E(\mathrm{MPa})$ & - & - & 100 & 40 & 10.55 & 210000 & - \\
\hline$E A(\mathrm{kN} / \mathrm{m})$ & - & - & - & - & - & - & 525 \\
\hline$v$ & - & - & 0.35 & 0.4 & 0.33 & 0.33 & - \\
\hline$v_{u r}$ & 0.2 & 0.2 & - & - & - & - & - \\
\hline$c\left(\mathrm{kN} / \mathrm{m}^{2}\right)$ & 0.0 & 0.0 & 0.0 & - & - & - & - \\
\hline$\varphi($ degree $)$ & 50 & 45 & 45 & - & - & - & - \\
\hline$\Psi$ (degree) & 0 & 0 & 0 & - & - & - & - \\
\hline $\operatorname{Pref}\left(\mathrm{kN} / \mathrm{m}^{2}\right)$ & 100 & 100 & - & - & - & - & - \\
\hline$m$ & 0.5 & 0.5 & - & - & - & - & - \\
\hline$K_{o}^{n c}$ & 0.3 & 0.3 & - & - & - & - & - \\
\hline$R_{f}^{o}$ & 0.9 & 0.9 & - & - & - & - & - \\
\hline
\end{tabular}

HS $=$ Hardening-Soil model, $\mathrm{MC}=$ Mohr-Coulomb model, $\gamma=$ unit weight, $E_{50}^{\text {ref }}=$ secant stiffness at $50 \%$ strength for loading conditions, $E_{u r}^{r e f}=$ triaxial unloading/reloading stiffness, $E_{\text {oed }}^{\text {ref }}=$ tangent stiffness for primary oedometer loading, $E A=$ elastic normal (axial) stiffness, $v=$ Poisson's ratio for loading conditions, $v_{u r}=$ Poisson's ratio for unloading/reloading conditions, $c=$ effective cohesion, $\varphi=$ effective friction angle, $\Psi=$ dilatancy angle, $P_{\text {ref }}=$ reference confining pressure, $m=$ stress dependent stiffness factor, $k_{o}^{n c}=$ coefficient of earth pressure at rest for normal consolidation, $R_{f}=$ failure ratio.

sleeper-ballast interface as a typical 25 tonne/axle traffic load with a frequency of $15 \mathrm{~Hz}$ (speed of $80 \mathrm{~km} / \mathrm{h}$ ). In the finite element analysis, this load was applied over 100 cycles and then the results were compared to the experimental data with the same number of cycles. A laterally distributed static load was also applied to the movable steel wall of the prismoidal rig to simulate a field confining pressure of $10 \mathrm{kPa}$.

Geosynthetics were initially placed $300 \mathrm{~mm}$ beneath the sleeper at the ballast capping interface, and then at decreasing intervals of $50 \mathrm{~mm}$ so that placement could be examined at 250, 200, 150 and $100 \mathrm{~mm}$ deep, respectively. Figure 17 demonstrates that there is a threshold depth (between 150 to $200 \mathrm{~mm}$ ) below which the geosynthetics contribute no further and provide less assistance for reducing settlement. According to Figure 17, the optimum location of geosynthetics for improving the deformation characteristics of recycled ballast may be taken as $200 \mathrm{~mm}$. Nevertheless, with ballast that is a conventional $300 \mathrm{~mm}$ thick, the optimum placement of geosynthetics at $200 \mathrm{~mm}$ deep may not be feasible for maintenance reasons, as mentioned earlier. In cases such as these, the layer of geosynthetics may still be conveniently located at the ballast/capping interface.

\subsection{Numerical modelling using $P F C^{2 D}$}

Ballast breakage under repeated loads depends on two major factors, i.e. confining pressure and angularity of the ballast particles. Hossain et al (2007) developed a numerical model using the Discrete Element Method (DEM) to investigate the effect of breakage on the stress-strain behaviour of ballast under different confining pressures. Irregularly shaped particles of ballast were considered and their angularity was modelled by clumping upto nine circular particles together to form single particles of twelve different shapes. Figure 18 shows four different shaped particles used in the analysis. A new subroutine that defines the breakage criteria based on splitting the tensile strength of cylindrical specimens was developed and incorporated in the $\mathrm{PFC}^{2 \mathrm{D}}$ analysis to study and quantify breakage in 


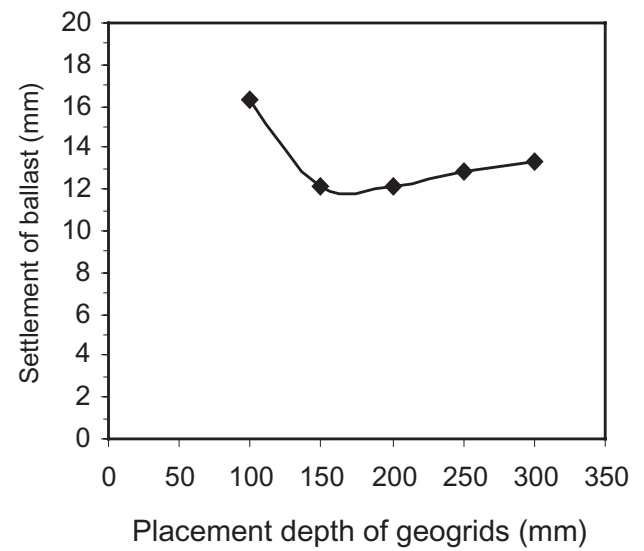

Figure 17. Optimum location of geosynthetics by the finite elements (Indraratna et al. 2005).

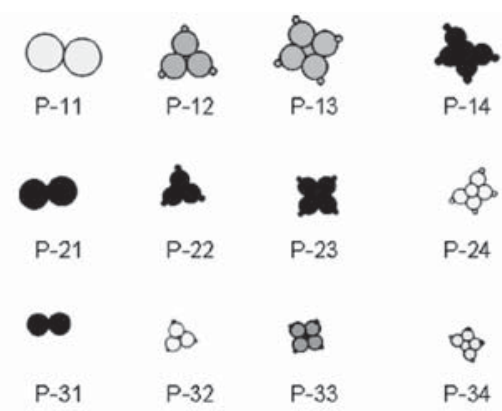

Figure 18. Particle shape and size considered in the numerical simulation (Hossain et al. 2007).

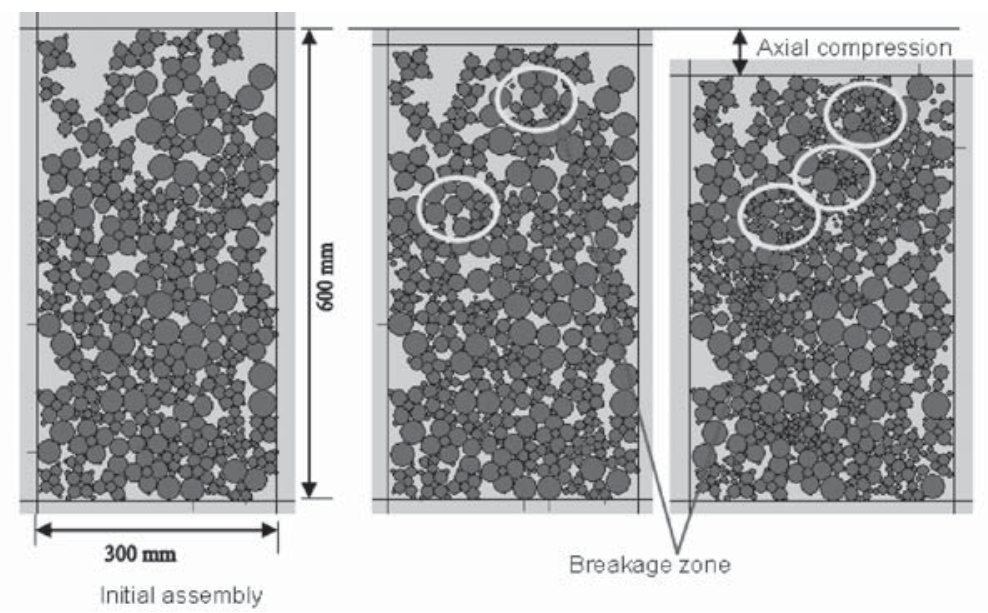

Figure 19. Assembly deformation including breakage (Hossain et al. 2007).

relation to the particle size distribution. The particles were within the size range 19-63 mm. Low values of confining pressure were used (upto $50 \mathrm{kPa}$ ). The general assembly of angular particles undergoing breakage is shown in Figure 19.

Figure 20 shows a comparison between the ballast breakage index (BBI) and laboratory experiments. It verifies that minimum breakage occurs at a confining pressure close to $30 \mathrm{kPa}$. At low values of $\sigma_{3}^{\prime}(>30 \mathrm{kPa})$, corner breakage is pronounced due to dilation but at increasing values of 


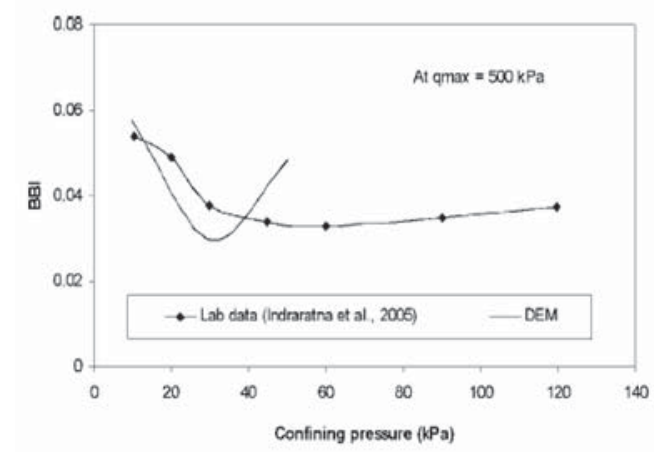

Figure 20. Comparison of ballast breakage index (BBI) with different confining pressure (Hossain et al. 2007).

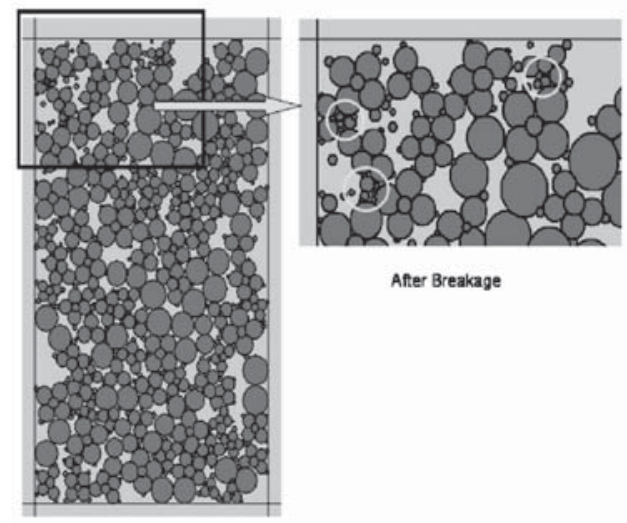

Figure 21. Breakage of particles at locations near the top plate (Hossain et al. 2007).

$\sigma_{3}^{\prime}(>30 \mathrm{kPa})$ the granular materials are compressed. At these elevated confining pressures, the granular assembly suffers from corner breakage and splitting. Dilation occurs at low levels of $\sigma_{3}^{\prime}$. Nevertheless, in most instances, the breakage zones were closer to the top loading platen due to a lower coordination number between the irregular particles, as shown in Figure 21. Research is currently being carried out at the University of Wollongong to develop a numerical model that uses PFC ${ }^{2 \mathrm{D}}$ and the effects of frequency (high speed trains) and anisotropy on the behaviour of ballast.

\section{FIELD TESTS ON INSTRUMENTED TRACK AT BULLI}

In order to validate the results of the elasto-plastic stress-strain constitutive model (Indraratna \& Salim, 2002, Salim \& Indraratna, 2004) and the results of laboratory experiments (Indraratna \& Salim 2005; Salim 2004), field tests were carried out on a real instrumented track. The University of Wollongong provided specifications for the track while funding to build a section of highly sophisticated instrumented track was provided by RailCorp, Australia. The overall track bed thickness was kept as $450 \mathrm{~mm}$ including a ballast layer of $300 \mathrm{~mm}$ and a capping layer of $150 \mathrm{~mm}$ in thickness. The particle size, gradation, and other index properties of ballast used at the Bulli site were in accordance with the Technical Specification TS 3402 (RailCorp, Sydney) which represents sharp angular coarse aggregates of crushed volcanic basalt (latite). Recycled ballast was collected from a recycled plant commissioned by RailCorp at their Chullora yard near Sydney. A physical examination indicated 
that about $90 \%$ of the recycled ballast was semi-angular crushed rock fragments, while the remaining 10\% consisted of semi-rounded river gravels and other impurities (Indraratna \& Salim, 2005). Most of the semi-angular particles of recycled ballast were almost the same size and shape as fresh ballast, except that these were less angular, had fewer asperities, and fouled with subgrade soils. The concrete sleepers were used. Four sections were constructed, as shown below (see Figure 22).

1. Fresh Ballast

2. Fresh Ballast and a geogrid/geotextile composite at the capping ballast interface

3. Recycled Ballast and a geogrid/geotextile composite at the capping ballast interface

4. Recycled Ballast

Observations of vertical and lateral deformations and the distribution of cyclic stresses in the ballast layer were made. The performance of each section under the cyclic load of moving trains was observed. Vertical deformations at different sections were measured by pegs and lateral deformations were measured by transducers connected to a data logger. The settlement pegs and displacement transducers were installed beside the rail and at the end of the sleeper, as shown in Figure 23. Figure 24 shows the installation of pressure cells to record vertical and lateral maximum cyclic stresses in the track.

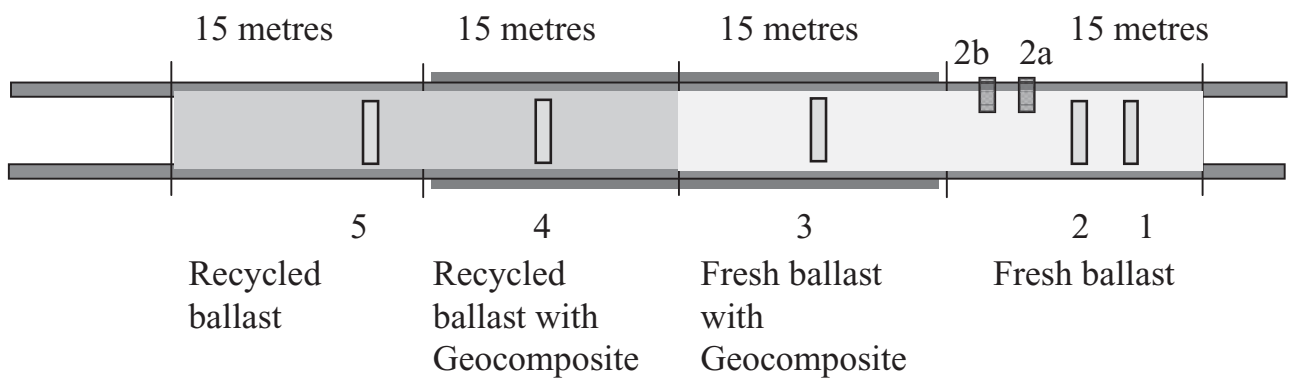

Figure 22. Layout of the test track on the down main at Bulli on the NSW South Coast.

Figure 23. Installing settlement pegs and displacement transducers.

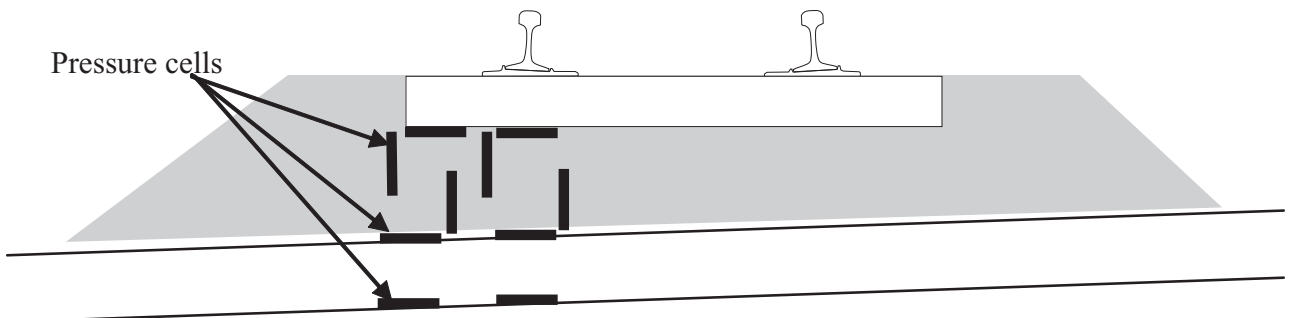

Figure 24. Installing pressure cells beneath the concrete sleeper. 


\subsection{Ballast lateral deformations}

Data from the displacement transducers was collected from the data logger at regular intervals. A summary of the final lateral deformations $\left(S_{h}\right)$ is presented in Table 3 to compare with the performance of different sections of track under cyclic loads. It reveals reveal how geosynthetics in the ballast layer significantly affect the lateral deformations of the ballast layer. The performance of fresh and recycled ballast was compared (refer Figure 22 locations 1 and 5) and showed a 12\% and 38\% decrease in lateral deformation $\left(S_{h}\right)$ beneath the sleepers and ballast, respectively, because recycled ballast was used. This particular recycled ballast performed very well, that is, showed less lateral deformations because it was more well-graded than the fresh ballast. If placed as a well graded mix the corners may not break so frequently because their angularity is less. The layer of geocomposite also reduced the lateral deformation of both fresh and recycled ballast significantly.

\subsection{Maximum stresses in ballast}

Figure 25 shows the maximum stress recorded in the ballast for an 82 class locomotive moving at about $60 \mathrm{~km} / \mathrm{h}$. The maximum vertical stress under the rail was reduced by $73 \%$ and $20 \%$ at the base of the ballast layer and capping layer, respectively.

Whereas the maximum vertical stress at end of sleepers showed a reduction of $64 \%$ and $45 \%$ at the base of ballast layer and capping layer, respectively. However, the horizontal stress decreased marginally with depth, as is evident from Figure 25. Figure 26 shows the maximum stress recorded in the ballast for a coal train with $100 \mathrm{~T}$ wagons. It confirms the same trend for vertical and horizontal stress recorded under the rail and at end of the sleepers.

Figure 27 shows the comparison of lateral strain $\left(\varepsilon_{3}\right)$ against the number of load cycles $(N)$ plotted in a semi-logarithmic scale with results of laboratory studies reported by Indraratna $\&$ Salim (2005) using the prismoidal triaxial apparatus. The lateral strain of ballast layer $\left(\varepsilon_{3}\right)$ is obtained by dividing the lateral deformation $\left(S_{h}\right)$ by the initial lateral dimension (considered

Table 3. Summary of the final lateral deformation of the ballast layer.

\begin{tabular}{llll}
\hline & & \multicolumn{2}{l}{$\begin{array}{l}\text { Lateral deformation } S_{h}(\mathrm{~mm}) \\
\text { measured underneath }\end{array}$} \\
\cline { 3 - 4 } Locations & Description of section & Sleepers & Ballast \\
\hline 1 & Fresh ballast & 10 & 6.5 \\
3 & Fresh ballast with geocomposite & 8.2 & 3.8 \\
4 & Recycled ballast with geocomposite & 7.8 & 5.3 \\
5 & Recycled ballast & 8.8 & 4 \\
\hline
\end{tabular}
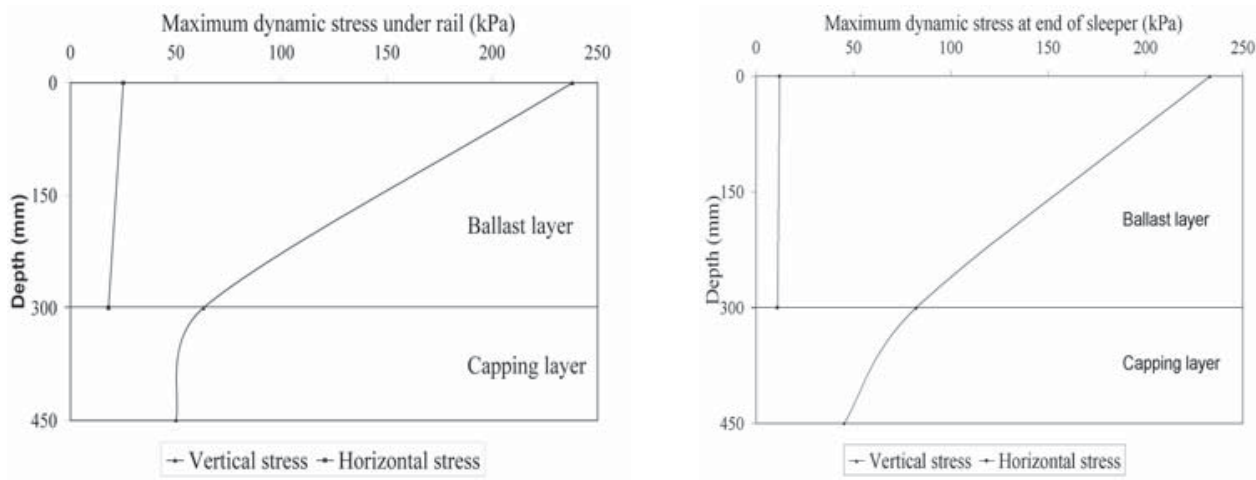

Figure 25. Maximum dynamic pressure measured (a) under the rail (b) at end of the sleepers for an 82 class locomotive. 

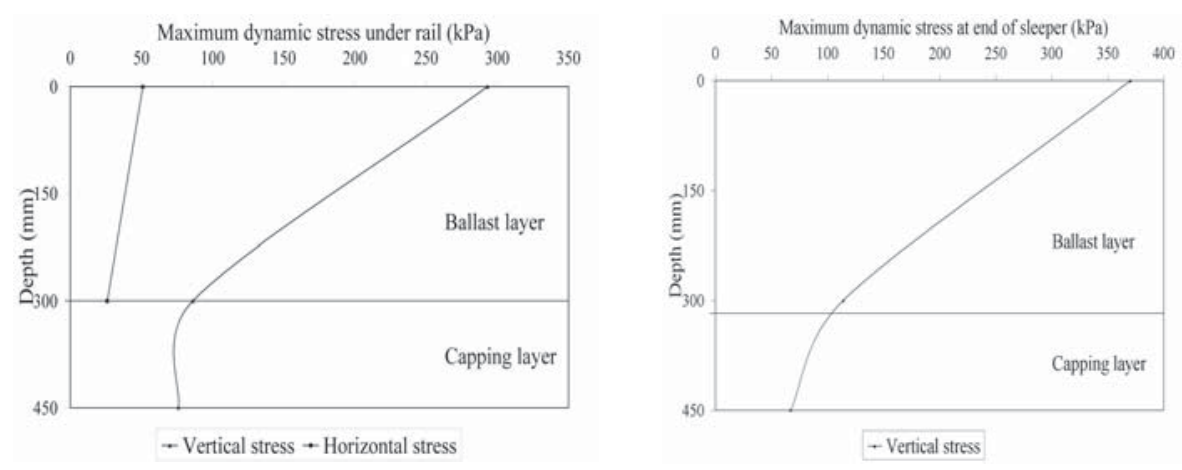

Figure 26. Maximum dynamic pressure measured (a) under rail (b) at end of sleepers for 100T coal wagon.

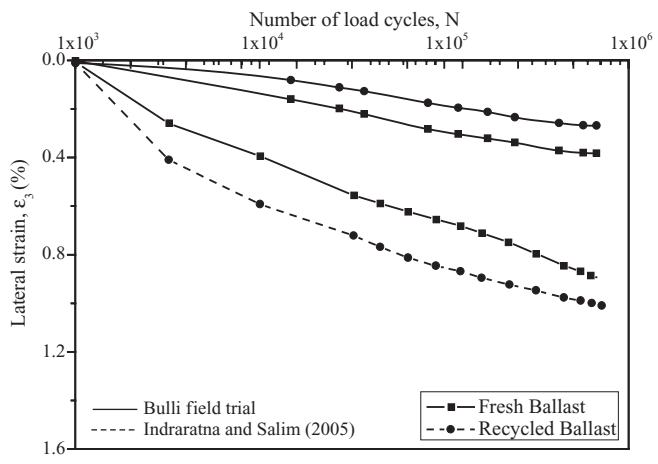

Figure 27. Comparison of lateral strain $\left(\varepsilon_{3}\right)$ with laboratory studies reported by Indraratna \& Salim (2005).

as $2.5 \mathrm{~m}$ ) of the ballast layer. Indraratna \& Salim (2005) used a slightly different track bed configuration as described earlier. They used a maximum cyclic vertical stress of $460 \mathrm{kPa}$ corresponding to an axle load of 25 tons and frequency of $15 \mathrm{~Hz}$ (Eseveld, 2001). It is observed that the nature of variation of $\varepsilon_{3}$ measured in Bulli test track is in acceptable agreement with those reported by Indraratna \& Salim (2005). The well-graded recycled ballast used in the Bulli field trial showed smaller $\varepsilon_{3}$ values compared to those of fresh ballast.

The observations recorded in the instrumented section of track at Bulli validate the analytical, numerical, and laboratory investigations carried out at the University of Wollongong and highlight the successful inclusion of geocomposite reinforcement in the rail track structures to significantly reduce the deformation and degradation of ballast. One interesting observation was the impact of a wheel flat where the maximum pressure transmitted to the ballast reached $415 \mathrm{kPa}$ on one occasion. A longer maintenance cycle is possible with the use of geosynthetics in the rail track which in turn help defray the high costs associated with maintaining ballasted tracks.

A decision support system (DSS) can serve as a suitable framework to improve the effectiveness and efficiency of decision making to evolve at technically and financially feasible solutions (Lemass \& Thompson, 2001). A DSS is defined as an interactive computer-based system that utilises a model to identify and draw upon relevant data in order to aid decision making. Currently, a DSS is being developed to assist industry partners with the selection of appropriate track maintenance cycles.

\section{CONCLUSIONS}

The performance of ballasted rail tracks with geosynthetic reinforcement has been described through laboratory, theoretical modelling, and numerical simulations. The complex deformation 
and degradation mechanisms have been modelled by elasto-plastic constitutive relations incorporating dilatancy and particle breakage. The results highlight that particle breakage and confining pressure have a significant influence on the permanent deformation of ballast. The resilient modulus was influenced by the number of cycles, maximum deviator stress, confining pressure, and particle breakage. Ballast breakdown increases with confining pressure, a phenomenon attributed to the inability of the ballast assembly to dilate under high levels of confinement. A new ballast breakage index (BBI) was used to quantify degradation. During cyclic loading, breakage was most significant at low and high values of confining pressure, with minimal breakage at some intermediate value. The degradation of ballast may be characterised into three distinct zones, dilatant unstable degradation zone (DUDZ), optimum degradation zone (ODZ), and compressive stable degradation zone (CSDZ). An increase in confining pressure to an optimal range of $30-75 \mathrm{kPa}$ causes minimum breakage, improves track performance, and reduces the need for costly maintenance. Of several measures used to increase the confining pressure, reinforcing geosynthetics is considered to be more suitable and economically viable.

The performance of ballasted track was evaluated when geosynthetic reinforcement was used. This study confirms that numerous forms of geosynthetic layers improve the performance of fresh ballast while its potential use along with recycled ballast was highlighted. It was shown that recycled ballast performs satisfactorily under repeated train loads when reinforced with suitable type of geosynthetics, eg, woven-geotextiles, geogrids and geocomposites. Settlement in fresh and recycled ballast was significantly reduced when geosynthetics were inserted.

A numerical model using the finite element approach (PLAXIS) was developed to determine the optimum location for a layer of geosynthetics layer in the ballast bed. It was shown that a threshold depth exists below which the layer of geosynthetics did not contribute to any further benefit and provided less assistance in reducing settlement. It was demonstrated that a layer of geosynthetics can be ideally located at the ballast/capping interface. A numerical model using the DEM approach $\left(\mathrm{PFC}^{2 \mathrm{D}}\right)$ was formulated to give a graphic insight into the real behaviour of granular material under cyclic loading. The results highlight that particle breakage and confining pressure have a significant influence on the permanent deformation of ballast.

The field tests carried out on the instrumented track at Bulli validated the findings of this study and also proved the benefits of using geosynthetics in rail track to minimise deformation and degradation. Use of geosynthetics in recycled ballasted track also proved to be a feasible and effective alternative. Imperfections such as wheel flat greatly increase the pressure on the ballast which causes deformation and degradation of ballast. Hence, occasional high impact loads stemming from imperfections in wheels and/or tracks are the subject of ongoing research at the University of Wollongong. Also, DSS is being developed from the measured field data to benefit Rail Industry.

\section{ACKNOWLEDGEMENTS}

The authors express their sincere thanks to Cooperative Research Center for Railway Engineering and Technologies (Rail-CRC), RailCorp (Sydney) and Polyfabrics (Sydney). A number of current and past doctoral students, namely, Dr. Daniela Ionescu, Dr. Joanne Lackenby, Dr. Wadud Salim, Dr. Mohamed. Shahin, Dr. Jayan Vinod, Mr Zakir Hossain and Mr. Pramod Thakur have participated to the contents of this paper; and their contributions are greatly acknowledged.

\section{REFERENCES}

Ashpiz, E.S., Diederich, R. and Koslowski, C. (2002). The use of spunbonded geotextile in railway track renewal on the St. Petersburg-Moscow line. In: Proceedings, 7th International Conference on Geosynthetics; 2002; Nice, France: 14-19.

Charles, J.A. and Watts, K.S. (1980). The influence of confining pressure on the shear strength of compacted rockfill. Geotechnique, London, U.K., 30(4): 353-367.

Chrismer, S.M. and Read, D.M. (1994). Examining ballast and subgrade conditions. Railway Track and Struct., AREA, 39-42. 
Esveld, C. (2001). Modern Railway Track, MRT-Productions, Netherlands.

Hicks, R.G. (1970). Factors influencing the resilient properties of granular materials. PhD thesis, University of California.

Hossain, Z., Indraratna, B., Darve, F. and Thakur, P.K. (2007). DEM analysis of angular ballast breakage under cyclic loading Geomechanics and Geoengineering: An International Journal, Vol. 2 (3): 175-181.

Indraratna, B., Ionescu, D. and Christie, D. (1998). Shear behaviour of railway ballast based on large-scale triaxial tests, Journal of Geotechnical and Geoenvironmental Engineering, ASCE, 124(5): 439-439.

Indraratna, B., Ionescu, D., Christie, D. and Chowdhury, R. (1997). Compression and Degradation of Railway Ballast under One-dimensional Consolidation, Australian Geomechanics Journal, December Issue: $48-61$.

Indraratna, B., Khabbaz, H., Salim, W. and Christie, D. (2003). Geotechnical characteristics of railway ballast and the role of geosynthetics in minimising ballast degradation and track deformation. In: RAILTECH 2003-Railway Technology in the New Millennium; 2003; Kuala Lumpur, Malaysia: 3.1-3.22.

Indraratna, B., Khabbaz, H. and Lackenby, J. (2003). Behaviour of railway ballast under dynamic loads based on large-scale triaxial testing. Proceedings of AusRAIL Plus 2003, Sydney, 8p.

Indraratna, B, Khabbaz, H, Salim, W, Lackenby, J, Christie D. (2004). Ballast characteristics and the effects of geosynthetics on rail track deformation. In: International Conference on Geosynthetics and Geoenvironmental Engineering, ICGGE; 2004; Bombay, India: 3-12.

Indraratna, B., Lackenby, J. and Christie, D. (2005). Effect of confining pressure on the degradation of ballast under cyclic loading. Geotechnique, 55(4): 325-328.

Indraratna, B. and Salim, W. (2002). Modeling of particle breakage of coarse aggregates incorporating strength and dilatancy. Geotechnical Engineering, Proceedings of the Institution of Civil Engineers, London, 155(4): 243-252.

Indraratna, B. and Salim, W. (2005). Mechanics of ballasted rail tracks-A geotechnical perspective, A. A. Balkema-Taylor and Francis, UK.

Indraratna, B, Salim W, Ionescu D, Christie D. (2001). Stress-strain and degradation behaviour of railway ballast under static and dynamic loading, based on large-scale triaxial testing. In: Proceedings, 15 th International Conference of Soil Mechanics and Geotechnical Engineering; 2001; Istanbul: 2093-2096.

Indraratna, B., Shahin, M.A. and Salim, M.W. (2005). Use of geosynthetics for stabilizing recycled ballast in railway track substructures. North American Geosynthetics Society (NAGS) - Geosynthetics Institute (GSI) Conference, Las Vegas, Nevada.

Indraratna, B., Vinod J.S. and Lackenby, J. (2008). Influence of particle breakage on resilient modulus of railway ballast, Geotechnique (in press).

Indraratna, B., Wijewardena, L.S.S. and Balasubramaniam A.S. (1993). Large-scale testing of greywacke rockfill, Geotechnique, 43(1): 37-51.

Lackenby, J., Indraratna, B. and McDowel, G. (2007). The Role of Confining Pressure on Cyclic Triaxial Behaviour of Ballast. Geotechnique, 57(6): 527-536.

Lemass, B.P. and Thompson, P. (2001). Decision Support for the Design of Residential Building Footing Systems. In S. Islam, L. Borle \& W. Keerthipala (Eds.), 2nd International Conference on Mechanics of Structures, Materials and Systems, Wollongong, Australia: 193-197.

Marachi, N.D., Chan, C.K. and Seed, H.B. (1972). Evaluation of properties of rockfill materials. Journal of Soil Mech. and Found. Division. ASCE, 96(6): 95-114.

Marsal, R.J. (1973). Embankment dam engineering - mechanical properties of rockfill, Wiley Publication, New York, 109-200.

PLAXIS. PLAXIS 2D Version 8.2-Finite element code for soil and rock analysis. Delft, The Netherlands: A. A. Balkema Publishers, 2004.

Raymond, G.P. (1979). Railroad Ballast Prescription: State-of-the-Art. Journal of the Geotechnical Engineering Division, ASCE, 105 (GT2): 305-322.

Raymond, G.P. (2002). Reinforced ballast behaviour subjected to repeated load. Journal of Geotextiles and Geomembranes, 20(1): 39-61.

Rowe, P.K. and Jones, CJFP (2000). Geosynthetics: innovative materials and rational design. In: Proceedings, GEOENG 2000; Melbourne, Australia: 1124-1156.

Salim, W. (2004). Deformation and degradation aspects of ballast and constitutive modelling under cyclic loading. PhD thesis, School of Civil, Mining and Environmental Engineering, University of Wollongong, Wollongonog.

Salim, W. and Indraratna, B. (2004). A New elasto-plastic constitutive model for granular aggregates incorporating particle breakage. Canadian Geotechnical Journal, 41(4): 657-671.

Selig, E.T. and Waters, J.M., (1994). Track Geotechnology and Substructure Management. Thomas Telford, London. 